THE BRILL SERIES OF LEONARDO STUDIES: 1

\title{
CARLO PEDRETTI
}

\author{
SEVENTY YEARS \\ OF HIS LEONARDO SCHOLARSHIP
}

(1944-1914)

A FESTSCHRIFT

EDITED BY

CONSTANCE MOFFATT

\&

SARA TAGLIALAGAMBA

\section{BRILL}




\title{
One for the Books: A Bibliographical "Gleaning” for CP
}

\author{
Max Marmor ${ }^{1}$
}

Carlo Pedretti’s 2008 intellectual autobiography, evocatively entitled Leonardo \& Io, is not really an autobiography at all. It is actually, as the subtitle makes clear, a personal retrospective on "half a century of [Leonardo] research between Europe and the United States"much of that research conducted by the prolific Pedretti himself, on both sides of the Atlantic. ${ }^{2}$ Not the least of the book's virtues is that it provides a helpful guide to, and in some cases handy reprints or summaries of, many of the author's more fugitive publications, which are trivial neither in number nor in importance. For unlike many great scholars, Carlo Pedretti has never disdained to write for the popular press and a lay audience, and yet many of his "opera minora" have been overlooked even by Leonardisti.

At the same time, Leonardo \& Io is characteristically replete with tasty morsels of Vinciana, many of them-to the specialist at least-wonderfully arcane. It is no coincidence that Pedretti has made an art form of what he likes to call the "gleaning" (spigolatura), or the concise exploration of a highly specialized topic. This penchant persists throughout the ten volumes of the journal, Achademia Leonardi Vinci.

The present "gleaning" is meant to return the favor in a way that might meet with the approval of the recipient of this Festschrift. That it focuses specifically on a bibliographical slice of Vinciana seems especially appropriate. Pedretti has always taken a singular interest in the literature of Leonardo studies, as scholar and, as we now know, as book collector. For

\footnotetext{
${ }^{1}$ The author is especially grateful for paleographic assistance to Murtha Baca, currently Head of Digital Art History at the Getty Research Institute. Dr. Baca was formerly teaching assistant to Carlo Pedretti and then Assistant to the Director of the Armand Hammer Center for Leonardo Studies at UCLA, at a time when the author was keeper of the Elmer Belt Library of Vinciana. Thanks also for their kind help to Mark Santangelo (formerly Associate Museum Librarian, Onassis Library for Hellenic and Roman Art, Department of Greek and Roman Art, Metropolitan Museum of Art), to Robert Scott (Head, Digital Humanities Center, Columbia University Library), and to Barbara Rockenbach (Director of Humanities and History Libraries, Columbia University Library).

${ }^{2}$ Leonardo \& Io: un grande studioso racconta mezzo secolo di ricerche tra Europa e Stati Uniti (Milan: Mondadori, 2008),
} 
scattered throughout the 700 pages of Leonardo \& Io are allusions to the contents of the author's impressive personal library. ${ }^{3}$

Surprisingly few scholars are bibliophiles, and fewer still, notable book collectors. Carlo Pedretti is both. One has to imagine that his collecting resonates strongly with his singular interest in and unsurpassed knowledge of the entire corpus of the bibliography and historiography of Leonardo studies. Nor can it be an accident that for much of his scholarly career, Pedretti's professional center of gravity was the Elmer Belt Library of Vinciana at UCLA which, in addition to offering easy access to the immense body of literature on Leonardo, also has as a core element of its collecting mission the assembling of books known to have been owned, consulted or influenced by Leonardo. Bibliography and book collecting are, in all these several ways, at the core of Leonardo scholarship as conceived and exemplified by Carlo Pedretti.

Like most serious book collectors, Pedretti has always appreciated what book collectors call the "association value" of a given book - its provenance, its “association" with previous owners, including above all previous scholars, and most particularly when a great scholar owned and annotated the book in question. Even when such annotations do not make a significant contribution to scholarship, they can and often do both embody and convey a powerful sense of the continuity of scholarship across generations, a kind of passing of the bibliographical and scholarly torch. ${ }^{4}$

Admittedly, like book collecting itself, the cultivation of "association value," carried to extremes, can resemble a cult. Sometimes after all (and with apologies to Freud) marginalia are merely “marginal." Recognizing that risk, it seems nonetheless appropriate to briefly recount a particular case of association value in the specialized literature of Leonardo studies. Appropriately, and adding yet another bibliographical layer to our story, this instance concerns a unique copy of the pioneering monograph on Leonardo's own personal library, and the fate of

\footnotetext{
${ }^{3}$ Thus toward the end of the book (Leonardo \& Io, p.601), in alluding to the two earliest editions (1550 and 1568) of Vasari's Vite (Lives of the Artists), the author notes in an aside that both titles are "present in splendid examples in my library" (entrambe presenti in splendidi esemplari nella mia biblioteca); for other references to the author's personal library, see pp.146, 196, and 659.

${ }^{4}$ For the catalogue of a memorable exhibition dedicated to the subject, see Roger E. Stoddard, Marks in Books (Cambridge, MA: Houghton Library, Harvard University, 1985).
} 
that very copy across the years, as it passed from scholar to scholar, all intent upon identifying the titles on Leonardo’s shelves.

\section{II}

In 1873, the great Milanese bibliophile Count Gerolamo d’Adda (1815-1881) ${ }^{5}$ published a pioneering study of “Leonardo da Vinci and his Library: notes of a Bibliophile” (Leonardo da Vinci e la sua libreria: note di un bibliofilo [Milan: s.n., 1873]), privately printed and distributed in a limited edition dedicated to Pietro Giuseppe Maggi (Fig. 1). Halfway through Leonardo \& Io (p.303), Pedretti turns his attention to d'Adda's rare opusculum.

\section{Figure 1: Gerolamo d'Adda, Leonardo da Vinci e la sua libreria (1873). Author’s copy}

Pedretti employs d'Adda's booklet as an overture to a discussion of aspects of Leonardo's personal library and its contents, writing:

An initial group of forty books owned by Leonardo and listed by him on a sheet of the Codex Atlanticus has been the object of learned interpretations on the part of scholars and bibliophiles, beginning with the famous contribution of Gerolamo d'Adda of 1873, an exceedingly rare little study of which only 75 copies were privately distributed, the subject being taken up again subsequently and

\footnotetext{
${ }^{5}$ On Gerolamo d'Adda see the obituary by P. Rotondi, “Il Marchese Gerolamo d'Adda,” Archivio Storico Lombardo IX (1882):[149]-161; E. Cantarella, “Girolamo d'Adda Salvaterra,” Dizionario Biografico degli Italiani, XXXI (1985) (online at http://www.treccani.it/enciclopedia/girolamo-d-addasalvaterra (Dizionario-Biografico)/; Gubernatis, Angelo de, Dizionario biografico degli scrittori contemporanei (Florence: Le Monnier, 1879), s.v. Adda (Marchese Girolamo d'). The contents of d'Adda's personal library are described in a supplementary volume to the catalogue of the library of Charles Fairfax Murray, who acquired d'Adda's book collection. See Catalogo dei libri posseduti da Charles Fairfax Murray, 2 vols. (London: privately printed by the Officina Poligrafica Romana, 1899) with the supplementary volume dedicated to a Catalogo dei libri posseduti da Charles Fairfax Murray provenienti dalla Biblioteca del Marchese Girolamo d'Adda (London, 1902).
} 
amplified by the same scholar in Richter's anthology of 1883. And precisely this little study was the basis of subsequent research into the sources of Leonardo's knowledge as conveyed by his direct and indirect references to printed books and manuscripts, research that found its first synthetic presentations in such systematic and fundamental works as those of Solmi and Duhem in the first decade of the $20^{\text {th }}$ Century.

Un primo gruppo di quaranta libri posseduti da Leonardo e da lui stesso elencati su un foglietto del Codice Atlantico databile intorno al 1490 è stato oggetto di erudite interpretazioni da parte di studiosi e bibliofili a cominciare dal celebre contributo di Gerolamo d'Adda del 1873, un rarissimo opuscolo di soli 75 esemplari fuori commercio, ripreso e ampliato dallo stesso autore nell'antologia del Richter del 1883. È quindi questo opuscolo la base di ulteriori ricerche sulle fonti del sapere di Leonardo anche attraverso altri suoi riferimenti diretto o indiretti a opera a stampa o manoscritte, ricerche che avrebbero avuto i primi sintetici in opera sistematiche e fondamentali come quelle del Solmi e del Duhem nel primo decennio del Novecento.

As Pedretti observes, Gerolamo d'Adda's research provided the foundation for Jean Paul Richter's important discussion of Leonardo's library in volume 2 of his pioneering anthology of The Literary Works of Leonardo da Vinci $\left(1^{\text {st }}\right.$ ed. 1883; $2^{\text {nd }}$ ed. 1939; $3^{\text {rd }}$ ed. 1970, with an invaluable Commentary by Pedretti, published in 1977). Thus, in his discussion of Leonardo's library Richter writes:

The late Marchese Girolamo d'Adda published a highly valuable and interesting disquisition on this passage [the list of books from the Codex Atlanticus] under the title: Leonardo da Vinci e la sua libreria; note di un bibliofilo (Milano 1873. Ed. di soli 75 esemplari; privately printed). In the autumn of 1880 the Marchese d' Adda showed me a considerable mass of additional notes prepared for a second edition. This, as he then intended, was to come out after the publication of this work of mine. After the much regretted death of the elder Marchese, his son, the Marchese Gioachino d'Adda was so liberal as to place these MS. materials at my disposal for the present work, through the kind intervention of Signor Gustavo Frizzoni. The following passages with the initials G. 
d'A. are reprints from the valuable notes in that publication, while the MS. additions I have marked [with an asterisk] *. I did not however think myself justified in reproducing here the acute and interesting observations on the contents of most of the rare books here enumerated. ${ }^{6}$

Bibliophiles will appreciate the fact that in his unpublished diaries, now at the Metropolitan Museum of Art, Richter recorded the date on which he acquired, through the good offices of Gustavo Frizzoni (1840-1919), a copy of d'Adda’s book, along with the author's manuscript notes, as just recounted. Richter's diary entry for April 20, 1882 reads "From M. d'Adda the Library of LdV Exemplar with his Notes” (Figs. 2a-2b).
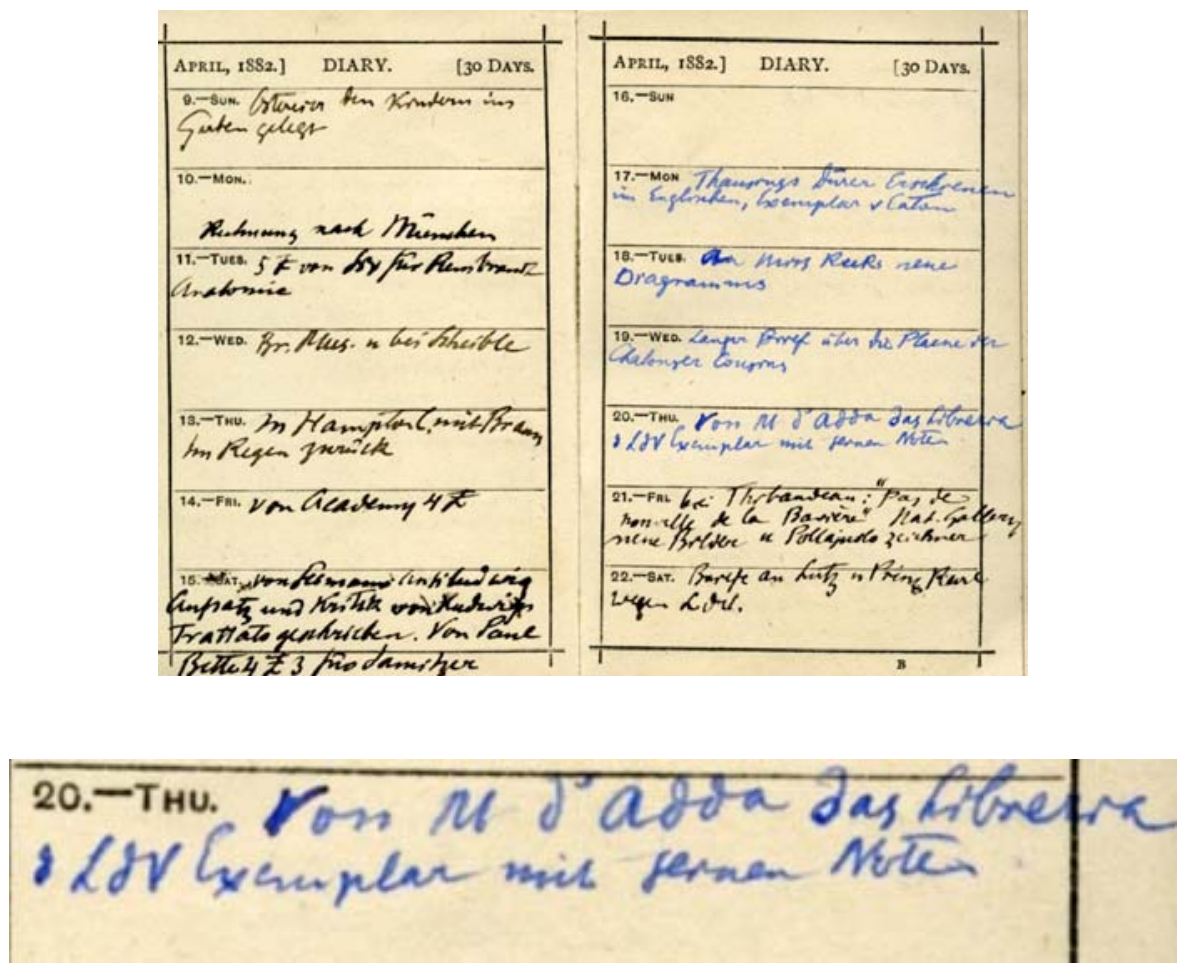

Figure 2a-2b: Jean Paul Richter diary, April 20, 1882 (with detail). The Onassis Library for Hellenic and Roman Art, The Metropolitan Museum of Art

${ }^{6}$ The Literary Works of Leonardo da Vinci, I, p.442, n. 1469. 
In 2008, an especially interesting copy of d'Adda's rare study appeared on the antiquarian book market, and the author of this essay had the good fortune to acquire it from the Milanese bookseller, Libreria Antiquaria Porta Venezia. Upon opening the bookseller's package two things became immediately apparent.

First, the copy in question (no. 37 of 75 privately distributed) was inscribed by the author on July 11, 1873 to his lifelong friend, Giambattista Passano (1815-1891), perhaps best known for (among many other learned works) a monumental history of anonymous and pseudonymous works of literature (Fig. 3). ${ }^{7}$ Amedeo Benedetti has recently published selections from the

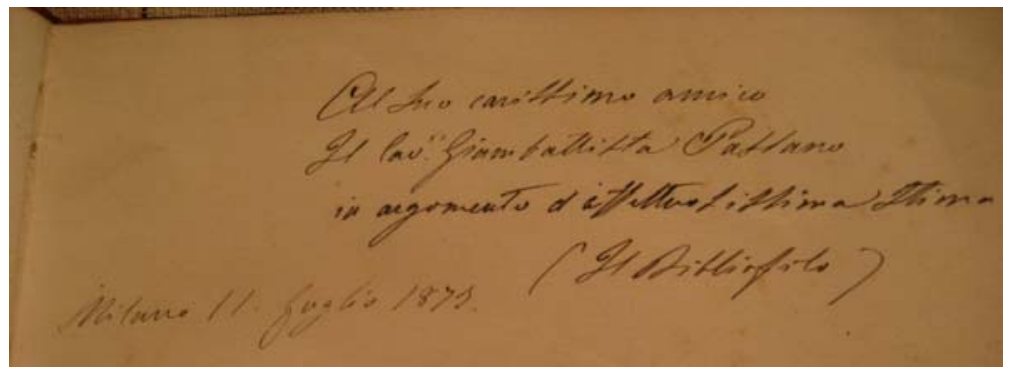

Figure 3: Inscription, author's copy of d'Adda, Leonardo da Vinci e la sua libreria (1873)

d'Adda-Passano correspondence, including, as it happens, a letter d'Adda sent to Passano on 11 July 1873, and in which the writer modestly alerts his friend to expect the delivery of his new book on Leonardo’s library. D’Adda writes: "With today’s mail you should receive a copy of my bibliographical scribble on the library of Leonardo da Vinci and I commend it to your friendly indulgence.”8

${ }^{7}$ Dizionario di opere anonime e pseudonime, in supplemento a quello di Gaetano Melzi, compilato da Giambattista Passano (Ancona: A.G. Morelli, 1887).

8 “Coll'ordinario d'oggi stesso riceverete un esemplare di un mio sgorbio bibliografico sulla biblioteca di Leonardo da Vinci e lo raccomando alla vostra amichevole indulgenza.” Letter number 28, dated 11 luglio 1873, in Amedeo Benedetti, “Girolamo d'Adda nelle lettere a Giovanni Battista Passano,” Storia in Lombardia 31/1 (2011): 113-161. Thanks to Professor Benedetti for a helpful email exchange concerning the fate of d'Adda's unpublished notes for a second edition of his book on Leonardo's library, discussed below. 
More important from the standpoint of Leonardo studies, it was also immediately apparent that the same copy of Gerolamo d'Adda's book had subsequently passed, by what path we do not know, from Passano's library to that of Gerolamo Calvi (1874-1934), author of the pioneering study of Leonardo da Vinci's manuscripts, their chronology, history, and biographical import, and whose armorial bookplate it bears (Fig. 4). ${ }^{9}$

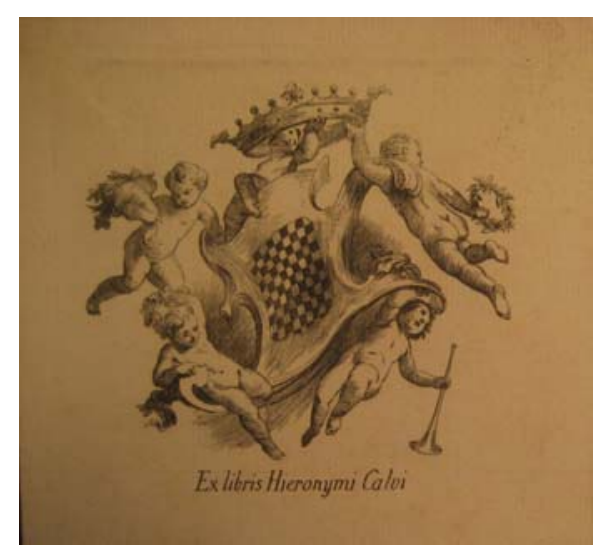

Figure 4: Bookplate of Gerolamo Calvi, from the author's copy of d'Adda, Leonardo da Vinci e la sua libreria

Finally, Calvi's copy of d'Adda's book arrived from the bookseller accompanied by dozens of manuscript notes, most if perhaps not all in Calvi's own hand, on slips of paper in various formats, inserted throughout the book. Calvi's notes range widely in their subject matter and include the following:

1) simple bibliographical references, mostly to the scholarly literature related to early editions of books listed by Leonardo as being in his possession; ${ }^{10}$

2) suggestions concerning specific editions of these books that might have been available to the artist, ${ }^{11}$ some with references to specific copies, known to Calvi, in various European libraries; ${ }^{12}$

\footnotetext{
${ }^{9}$ Gerolamo Calvi, I manoscritti di Leonardo da Vinci dal punto di vista cronologico, storico e biografico (Bologna: Zanichelli, 1925; reprint with an introduction by Augusto Marinoni [Busto Arsizio: Bramante, 1982]). In addition to d'Adda's book, several other books from Calvi's personal library were also offered for sale in Libreria Antiquaria di Porta Venezia’s “Catalogo Provvisorio n.1” (December 2008).

${ }^{10}$ Many of these references are to volumes of the Zeitschrift für romanische Philologie.
} 
3) speculations about Leonardo's sources, some taking the form of research desiderata; ${ }^{13}$

4) several notes reproducing d'Adda's published and unpublished observations as quoted in Richter's anthology (see above), seeking in all instances to follow Richter's practice of distinguishing between d'Adda's published remarks and his unpublished manuscript notes.

Calvi was evidently attempting to update his own copy of d'Adda's book by means of d'Adda's unpublished manuscript notes, as reproduced in Richter's anthology. The latter manuscript additions, designated by Richter (as we have seen) with an asterisk, are recorded as "aggiunte ms" by Calvi in his own notes.

In addition to these several categories of marginalia, Calvi's notes include an extended separatum on lined paper with a paper cover, labeled in pencil "Cronica desidero" and inscribed "G Calvi.” Calvi’s 14-page pamphlet is devoted to an extended series of annotated transcriptions from a copy of the famous Chronicle of Isidore of Seville (Cronico Isidoro), featuring both interspersed and marginal annotations. The text in question is listed in the Codex Atlanticus as being among Leonardo's books. D’Adda discusses it on p. 32 of his book and revisits it in his unpublished manuscript notes, as reproduced by Richter (p.444, n.19). Calvi notes on the first page of the pamphlet that the edition he consulted was "stampato in Cividal[e] del Friule 148024 Nov." and that it bore, "nell'incipit e explicit," the title "La Cronica De Sancto Isidero [sic]," also indicating that "the library at Como has a copy" (la bibl[iote]ca a Como a un esemplare). Presumably Calvi consulted that copy, the colophon of which he quotes verbatim on the penultimate page of his pamphlet, also noting the presence of several other early imprints in the library at Como.

${ }^{11}$ For example, in a note inserted before page 37 of his copy of d'Adda's book, Calvi suggests that Leonardo owned Ambrogio Traversari's (Latin) translation of Diogenes Laertius' Lives of the Philosophers (Credo queste vite siano nella lista de libri di L[eonar]do).

12 Thus in a note inserted before page 25 of d'Adda's book, Calvi refers to "Giuliani / 1869 [sic] coup d'oeil sur les bibliotheques d'Italie," a reference to Giambattista Carlo Giuliani, Colpo d'occhio alle Bibliotheche d'Italia ed in ispecialità alla communal di Verona ... (Verona: Giuseppe Civelli, 1867).

${ }^{13}$ In a note inserted before page 21 of d'Adda's book, where d'Adda touches on Leonardo's indication that he owned the first, third and fourth "decades" of Livy, Calvi writes that "one should find" (bisognerebbe trovare) an edition of Livy's Decades that lacks the second "decade" but includes the first and third.” Calvi then notes the existence of just such an edition (1502, reprinted 1511). 
In his annotations to these transcriptions, Calvi suggests that the Chronicle might be the source of some of Leonardo's famous literary "fantasie.” Thus he writes à propos of fol. 3v-4r of the Chronicle that "probably Leonardo, in his book with the story about the orient, intended to parody books of his own time - as with [cancelled out] those that rehearse too extensively the legendary part” (Probabilmente L[eonar]do nel suo libro con il racconto d'oriente ebbe intenzione di parodiare i libri del tempo - come con quelli che svolgevano troppo la parte leggendaria). Similarly, in transcribing and commenting upon fol. 6r of the Chronicle ("De Diluvio”), Calvi asks whether a passage about the Biblical Flood in Josephus might be related to “the regions of Leonardo’s prophecy?” (le regione della profezia di L[eonar]do?) Commenting on fol. 8v and the Chronicle's discussion of the Tower of Babel, Calvi refers to "Leonardo and the interest he could have taken in this book by reason of the references to the first soaring inventions (those in the Bible)" (L[eonar]do e l'interessa che potea trovarne in questo libro per gli accenni all prime invenzioni alte (quelle bibliche)." Still elsewhere, Calvi makes marginal reference to “Triv. $1 \mathrm{v}$ - nota abrusiati," a reference to fol.1v of Leonardo's Codex Trivulzianus, where the artist alludes to the estimated 700,000 books burned in the destruction of the great Library at Alexandria. Calvi notes on the preceding page of the pamphlet that "Isidoro's primary source is Orosius” (Il fonte principale d'Isidero [sic] è Orosio) and his marginal note accordingly refers to Orosius' account of the destruction of the Alexandrian Library. We know, thanks to Edmondo Solmi, that Leonardo's own source was Roberto Valturio, though the artist cites only Ammianus Marcellinus. ${ }^{14}$ Finally, toward the end of his pamphlet, Calvi notes that a passage in the Chronicle describing an eclipse of the sun, said by Orosius to have occurred in Rome in A.D.786, was "borrowed by LB Alberti but not by Leonardo" (LB Alb[erti] importerebbe questo L[eonar]do no).

Space limitations permit us to reproduce below only a representative selection of Calvi's notes, found in his copy of d'Adda's rare study of Leonardo's library. But the interested reader will find a full-text digital version of Calvi's copy of d'Adda's book in the Internet Archive, ${ }^{15}$

\footnotetext{
14 This suggests that Calvi acquired d'Adda's volume before he published his seminal study of Leonardo's manuscripts (n.9 above), since on p.130 of the latter, Calvi notes the derivation from Valturio. And elsewhere Calvi refers to d'Adda's study (p.142 n.) writing that d'Adda has "sagacamente commentato" upon the list of books in the Codex Atlanticus (though Calvi erroneously gives d'Adda's publication date as 1872 not 1873).

${ }^{15}$ https://archive.org/details/DAddaLeonardoELaSuaLibreria1873
} 
and high-resolution digital images of all Calvi's notes, presented in the sequence in which they were found in his copy of d'Adda's book, on the author's Academia.edu page. ${ }^{16}$

${ }^{16}$ https://independent.academia.edu/MaxMarmor/Documents 
Selected Notes by Gerolamo Calvi, inserted into his copy of Gerolamo d'Adda, Leonardo da Vinci e la sua libreria, note di un bibliofilo (Milan, 1873) 


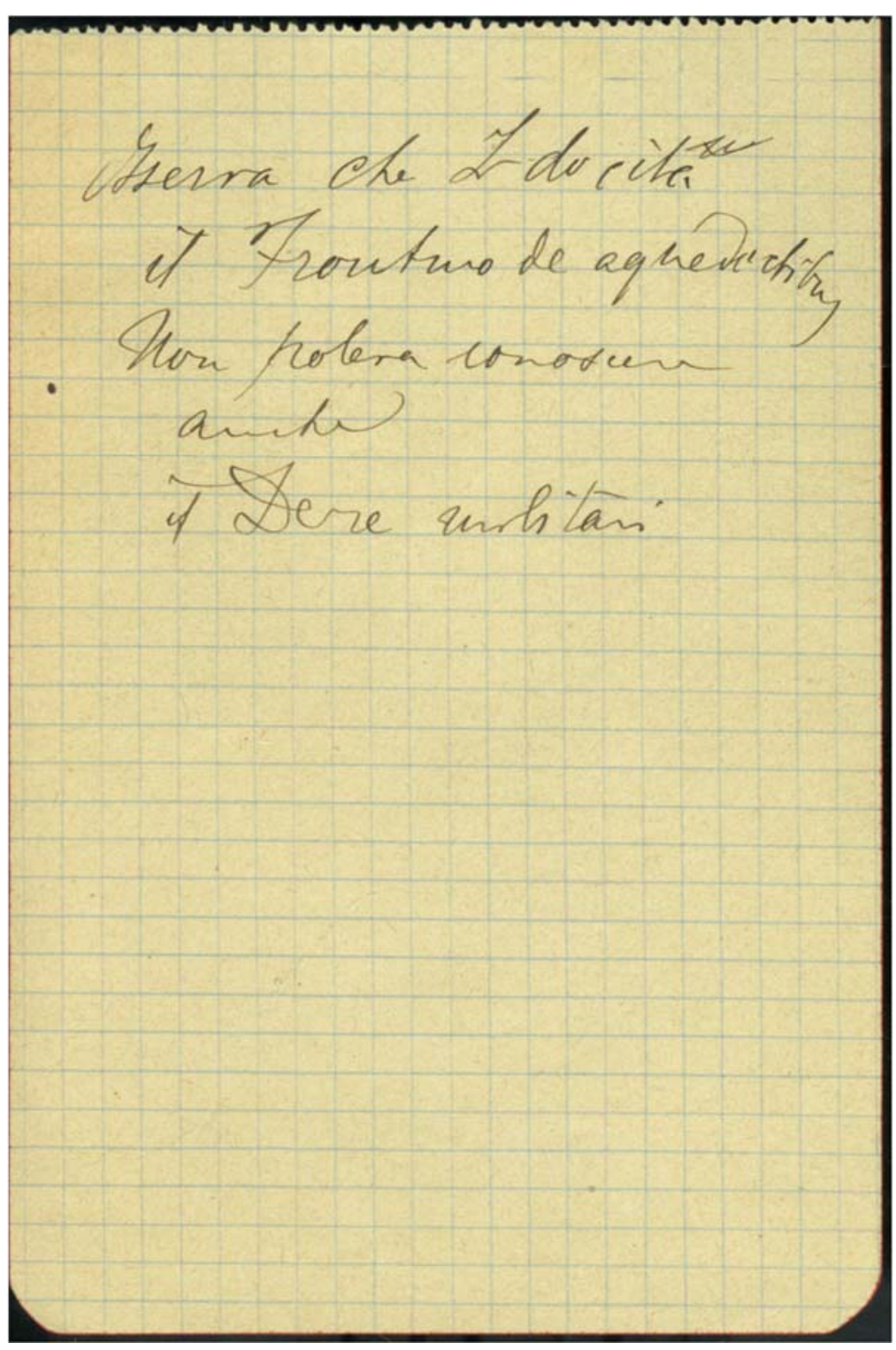

Figure 5: Calvi MS note reading "Osserva che L[eonar]do cita il Frontino de aqueductibus. Non poteva conoscere anche il De re militari." From Calvi's copy of d'Adda; note inserted between p.18-19. 


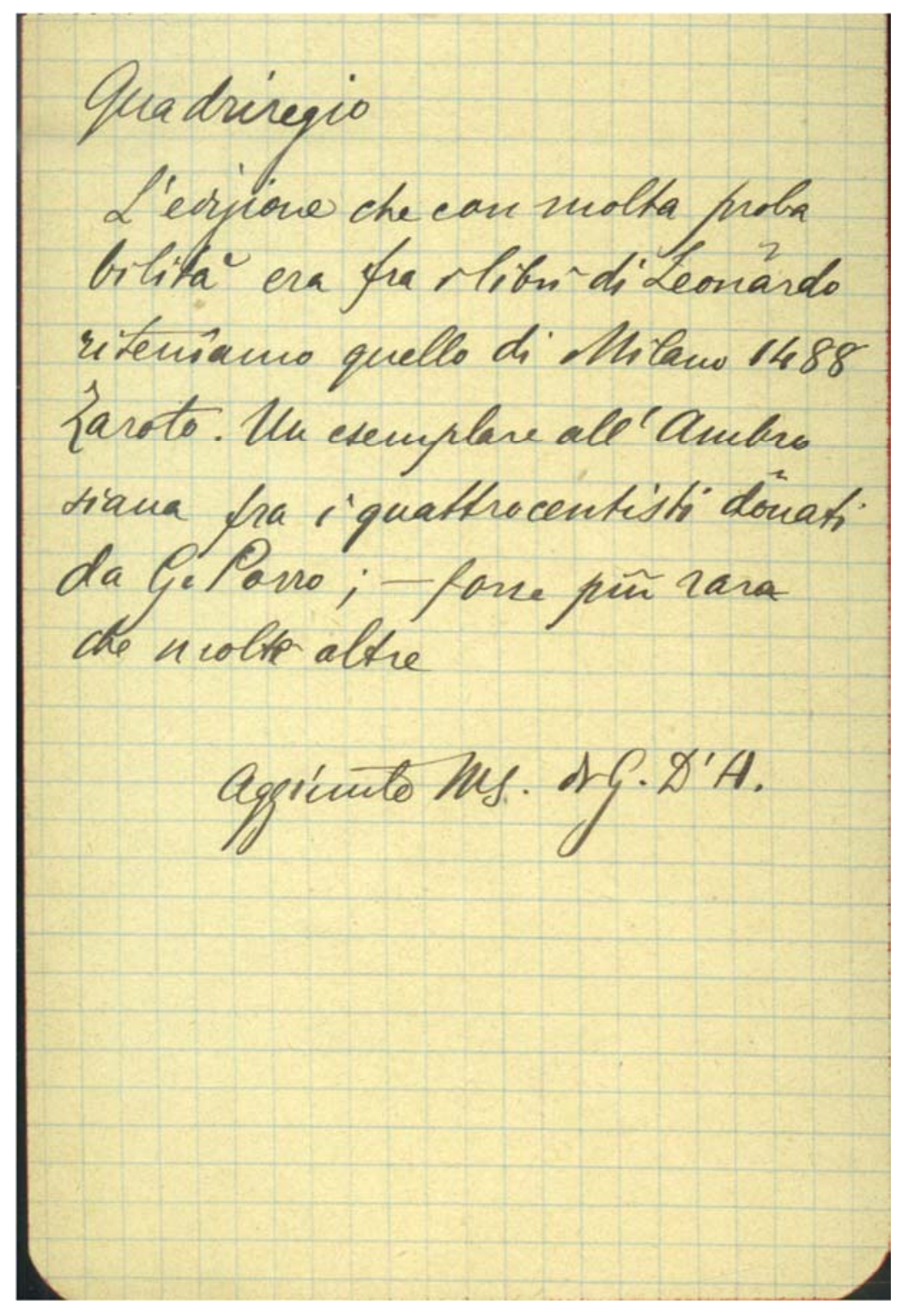

Figure 6: Calvi MS note, one of several transcriptions from Richter's discussion of Leonardo's library, noting in each instance passages taken from d'Adda's book and unpublished manuscripts. From Calvi's copy of d'Adda; note inserted between p.22-23. 


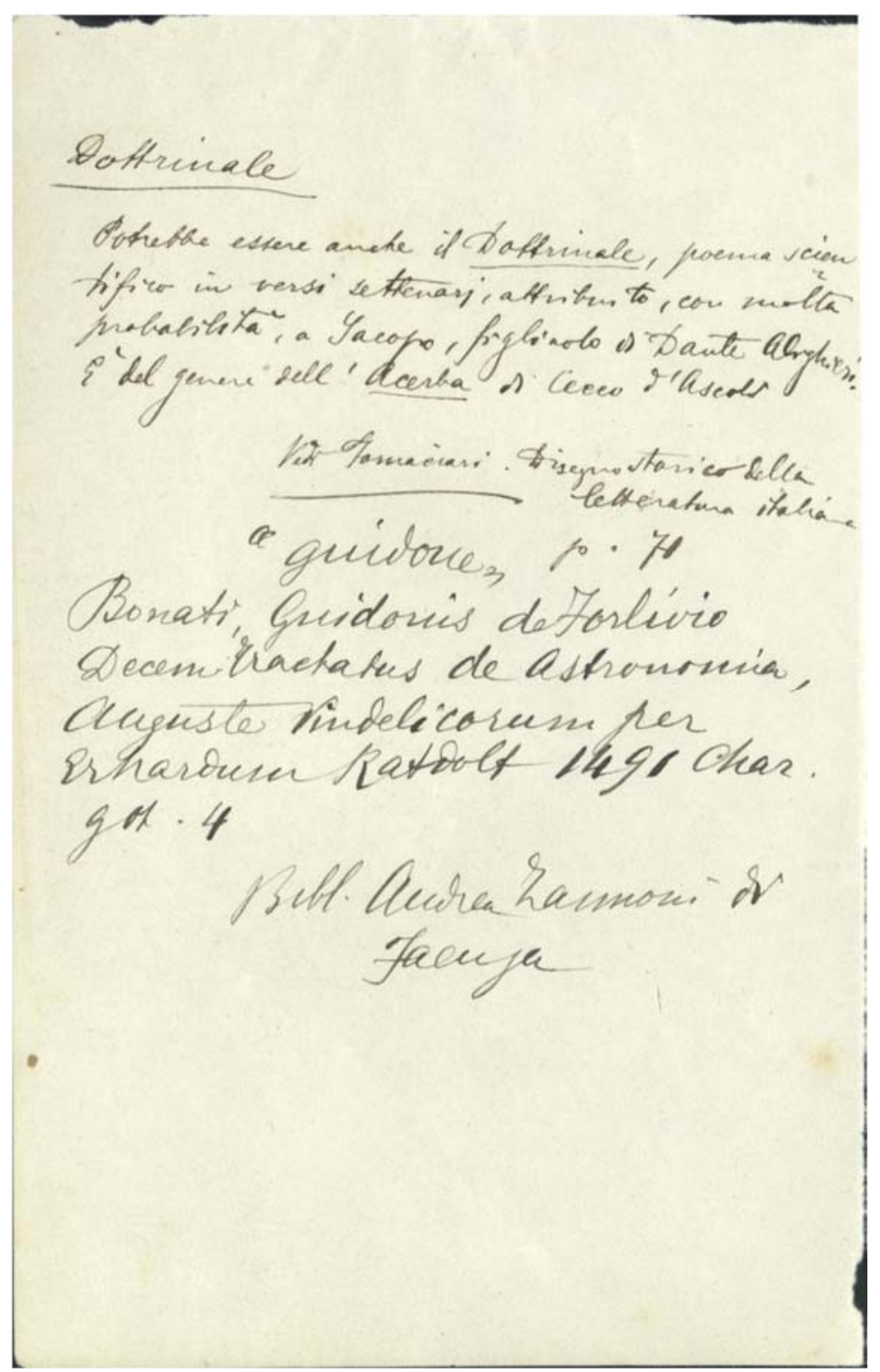

Figure 7: Calvi MS note, one of several notes speculating about a title ("Dottrinale") in Leonardo's book list. From Calvi's copy of d'Adda; note inserted between pages 24-25. 


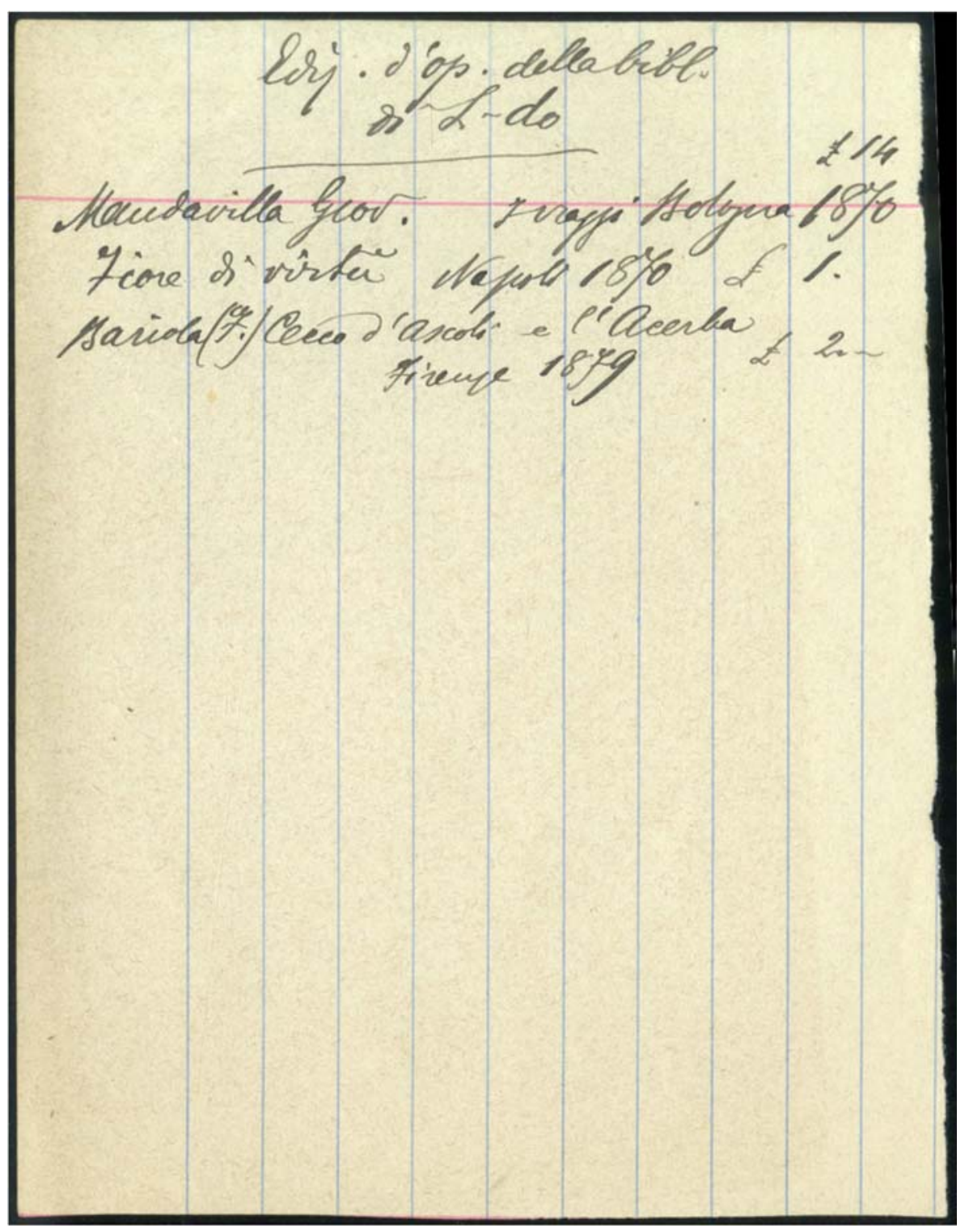

Figure 8: Calvi MS note reading "Ediz[ioni] d'op[ere] della bibl[ioteca] di L[eonar]do." From Calvi's copy of d'Adda; note inserted between p.26-27. 


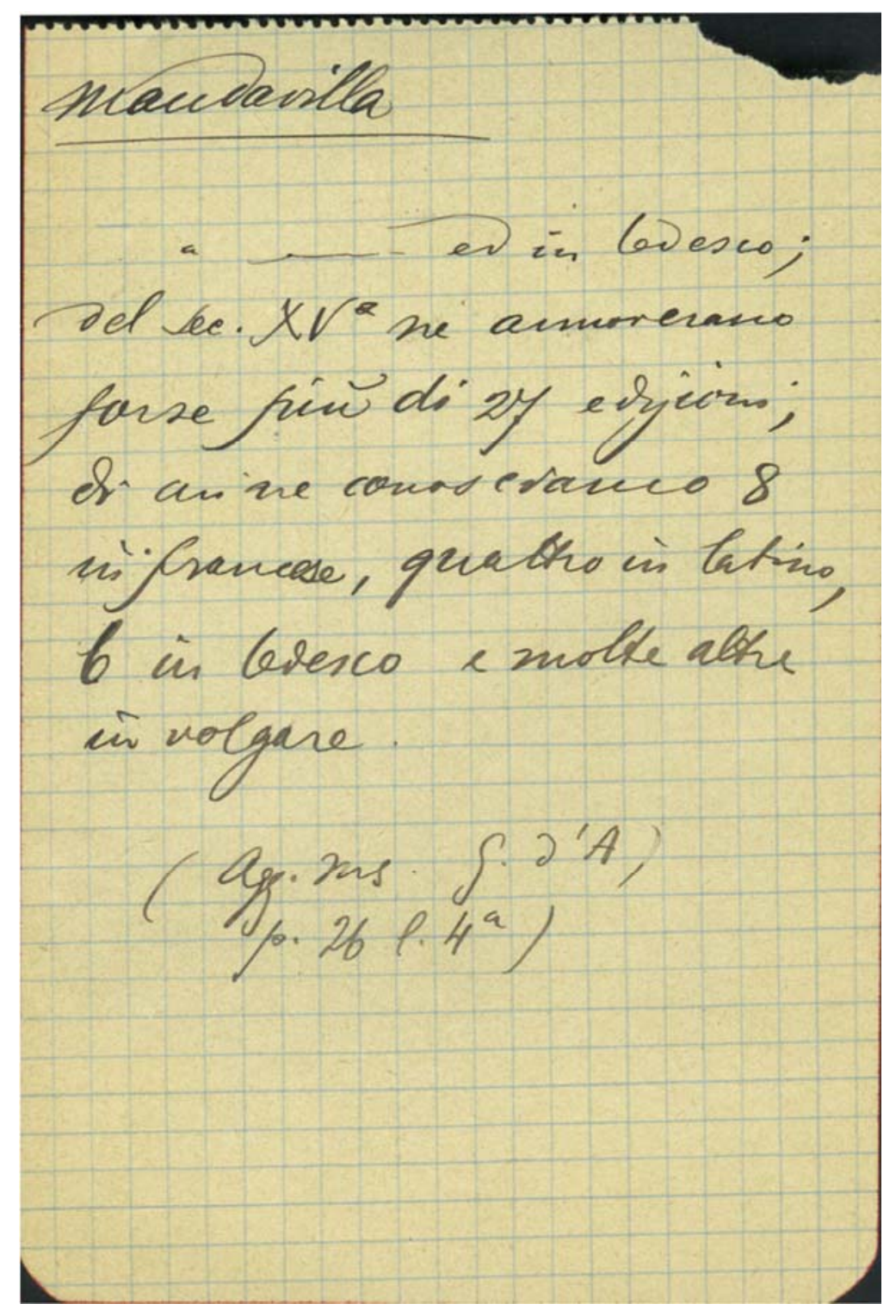

Figure 9: Calvi MS note, one of several transcriptions from Richter's discussion of Leonardo's library, noting in each instance passages taken from d'Adda's book and unpublished manuscripts as quoted by Richter, and in this case also indicating in parentheses that d'Adda discusses the title in question on p. 26, line 4a of his book. From Calvi's copy of d'Adda; note inserted between p.26-27. 


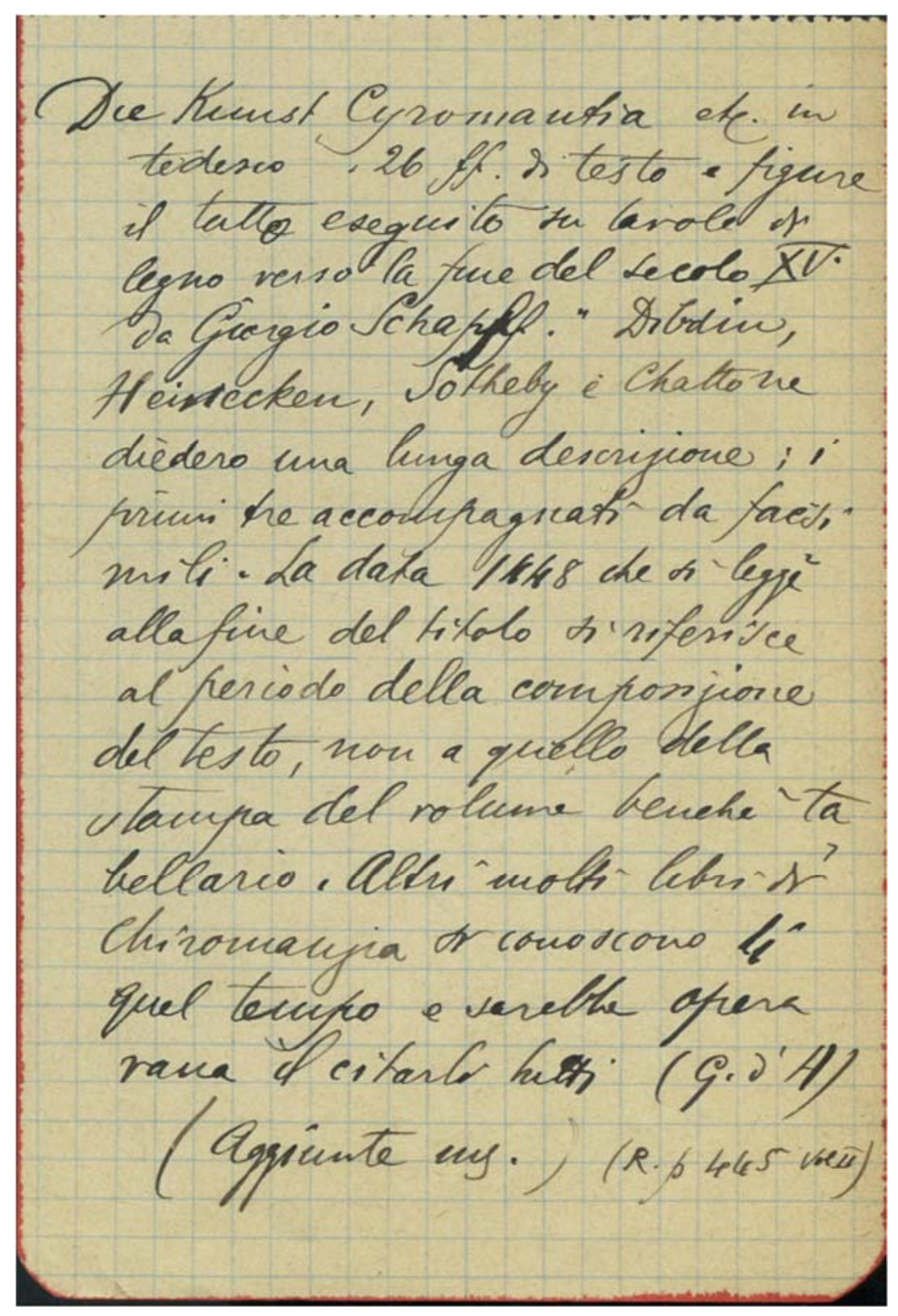

Figure 10: Calvi MS note, one of several transcriptions from Richter's discussion of Leonardo's library, noting in each instance passages taken from d'Adda's book and unpublished manuscripts, and in this instance also providing a parenthetical page reference to Richter. From Calvi's copy of d'Adda; note inserted between p.34-35. 


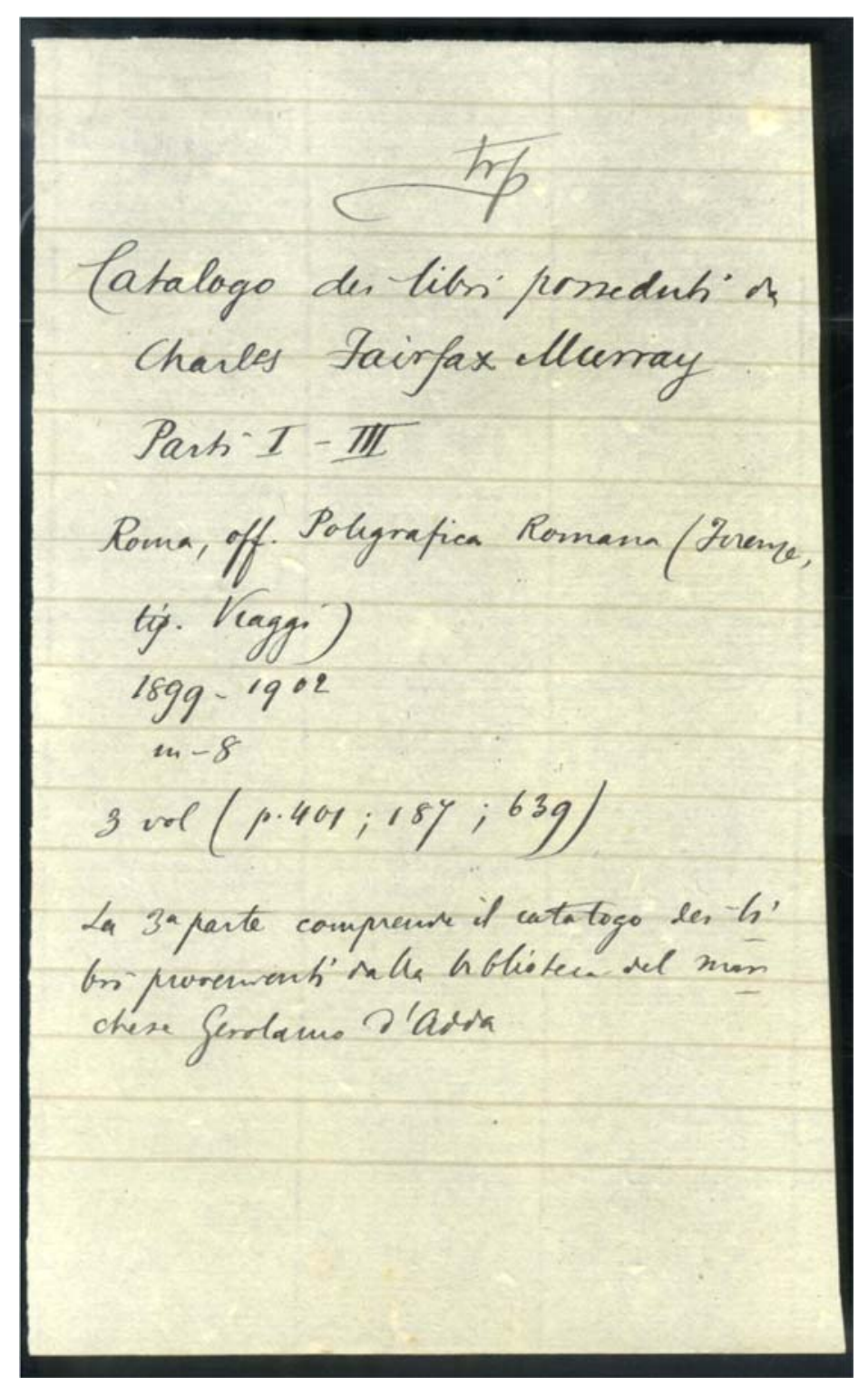

Figure 11: Calvi MS note about the catalogue of the private library of Charles Fairfax Murray, indicating that "the third part comprises the catalogue of books from the library of Marchese Gerolamo d'Adda," which was acquired by Fairfax Murray. From Calvi's copy of d'Adda; note inserted between p.28-29. 